\title{
PENGARUH PEMBERIAN TUMBUKAN BAWANG MERAH SEBAGAI PENURUN SUHU TUBUH PADA BALITA DEMAM DI PUSKESMAS LUBUK BUAYA KOTA PADANG TAHUN 2018
}

\author{
Faridah BD ${ }^{1}$, Elda Yusefni ${ }^{2}$, Ingges Dahlia Myzed $^{3}$ \\ ${ }^{1}$ Politeknik Kesehatan Kemenkes Padang \\ Email : faridahbd140@gmail.com \\ ${ }^{2}$ Politeknik Kesehatan Kemenkes Padang \\ Email : eldayusefni@gmail.com \\ ${ }^{3}$ Politeknik Kesehatan Kemenkes Padang \\ Email :dahliamyzed@gmail.com
}

\begin{abstract}
ABSTRAK
Demam adalah hal fisiologis yang biasa terjadi pada balita, demam dapat disebabkan oleh infeksi dan non infeksi. Berdasarkan data yang telah di dapatkan dari Dinas Kesehatan Kota Padang, sebanyak 5820 orang anak mengalami demam sepanjang tahun 2016 di Puskesmas Lubuk Buaya Kota Padang. Dari survey pendahuluan yang telah dilakukan, 2 dari 10 orang ibu telah menggunakan obat tradisional untuk mengatasi demam pada anaknya, tetapi menggunakan daun jarak. Tujuan penelitian ini untuk mengetahui pengaruh pemberian tumbukan bawang merah pada balita demam di Puskesmas Lubuk Buaya Kota Padang Tahun 2018. Metode penelitian eksperimental dengan jenis penelitian quasy eksperiment menggunakan rancangan one group pretest postest design. Penelitian dilakukan pada bulan Januari 2018 di Puskesmas Lubuk Buaya Kota Padang, jumlah sampel sebanyak 16 balita dengan menggunakan teknik pengambilan sampel purposive sampling. Instrumen yang digunakan lembar observasi dan termometer. Analisis data univariat dan bivariat menggunakan uji t dependen secara komputerisasi, dengan menggunakan SPSS. Hasil penelitian rata-rata suhu tubuh sebelum dilakukan pemberian tumbukan bawang merah yaitu $37,91^{\circ} \mathrm{C}$ dan setelah dilakukan pemberian tumbukan bawang merah yaitu $37,42^{\circ} \mathrm{C}$. Setelah dilakukan uji t paired sample didapatkan rata-rata selisih sebelum dan sesudah perlakuan adalah $-0,48$. $p$ value $=0,000<0,05$ sehingga Ho ditolak, artinya bawang merah efektif terhadap penurunan suhu tubuh pada balita demam. Kesimpulan didapatkan, bawang merah efektif sebagai penurun suhu tubuh pada balita demam. Diharapkan penelitian ini dapat dijadikan sebagai informasi terbaru mengenai obat-obatan herbal yang dapat dijadikan salah satu alternatif untuk menurunkan suhu tubuh pada balita yang demam.
\end{abstract}

Kata Kunci : Bawang Merah, Balita, Demam

Fever is a physiological thing that is common in infants, fever can be caused by infection and non infection. Based on data that has been obtained from Padang City Health Office, as many as 5820 children have fever during 2016 at Lubuk Buaya Community Center in Padang City. From the preliminary survey that has been done, 2 of 10 mothers have used traditional medicine to overcome the fever in their children, namely using leaf distance. The purpose of this study to determine the effectiveness of the use of red onion under fives under age 2 years in Puskesmas Lubuk Buaya Padang City Year 2018. Experimental research method with quasi experimental research using one group pretest postest design. The study was conducted in January 2018 at Puskesmas Lubuk Buaya Padang City, the number of sample 16 by using purposive sampling sampling technique. Instruments used observation sheets, thermometers and informed consent sheets. Analysis of univariate and bivariate data using $t$ test dependent with computerization. The results of the average body temperature before doing onion collision is $37.91^{\circ} \mathrm{C}$ and after doing the onion collision of $37.42^{\circ} \mathrm{C}$. After the paired simple $\mathrm{t}$ test obtained the average difference between before and after treatment is -0.48 . Ho is rejected with $p$ value $=0.000<0.05$ means that onion is effective against decreasing body temperature in fever toddlers. The conclusion of red onion is effective as lowering body temperature in fever toddlers. It is expected that this research can be used as the latest information about herbal medicines that can be used as an alternative to lower body temperature in fever.

Keywords: Red Onion, Fever, Toddlers 


\section{PENDAHULUAN}

Di Indonesia, anak yang mengalami demam terdapat 10-30 \% orang anak dari jumlah kunjungan. Berdasarkan data dari Dinas Kesehatan Kota Padang, sepanjang tahun 2016 di Kota Padang tercatat sebanyak 5820 orang anak mengalami demam. Demam bisa mengakibatkan kejang, kejang demam (febrile convulsion) adalah kejang pada bayi atau anak-anak yang terjadi akibat demam tanpa adanya infeksi pada susunan saraf pusat atau kelainan saraf lainnya. Di Indonesia dilaporkan angka kejadian kejang demam 2\% - 4\% dari anak yang berusia 6 bulan sampai 5 tahun pada tahun 2012-2013. Sedangkan angka kejadian kejang demam di Puskesmas Lubuk Buaya sendiri adalah 176 orang anak mengalami kejang demam sepanjang tahun 2016. ${ }^{2,3,4}$

Demam adalah mekanisme perlawanan tubuh terhadap infeksi virus atau bakteri. Demam biasanya tidak berbahaya, umumnya demam terjadi akibat infeksi biasa, seperti pilek dan nyeri lambung. Infeksi ini biasanya disebabkan virus dan dapat sembuh tanpa pengobatan. Demam karena infeksi dapat berlangsung relatif singkat. Dapat pula karena bakteri, seperti infeksi pada telinga, paru-paru, kandung kemih atau ginjal. Infeksi karena bakteri memerlukan antibiotik, demam dapat terjadi karena vaksinasi yang rutin dan bukan alasan untuk menghindari vaksin yang dianjurkan.

Demam terjadi bila berbagai proses infeksi dan noninfeksi berinteraksi dengan mekanisme pertahanan hospes. Pada kebanyakan anak demam disebabkan oleh agen mikrobiologi yang dapat dikenali dan dapat menghilang sesudah masa yang pendek. Demam pada anak dapat digolongkan sebagai (1) demam yang singkat dengan tanda-tanda yang mengumpul pada satu tempat sehingga diagnosis dapat ditegakkan melalui riwayat klinis dan pemeriksaan fisik, dengan atau tanpa uji laboratorium; (2) demam tanpa tanda-tanda yang mengumpul pada satu tempat, sehingga riwayat dan pemeriksaan fisik tidak memberi kesan diagnosis, tetapi uji laboratorium dapat menegakkan etiologi; (3) demam yang tidak diketahui sebabnya (fever unknown origin $=$ FUO. $)^{5}$
Secara umum penanganan untuk demam ada berbagai macam, diantaranya dapat ditangani dengan menggunakan kompres air hangat, menggunakan obat-obatan yang mengandung bahan kimia dan obat tradisional (obat herbal). Obat secara tradisional yang digunakan dalam mengatasi demam pada anak berfungsi sebagai penurun suhu tubuh diantaranya menggunakan daun jarak (obat luar), temulawak (obat oral / minum ), bawang merah ( obat luar) dan lainlain. ${ }^{1,7}$

Bawang merah adalah herba semusim, tidak berbatang, daun tunggal memeluk umbi lapis, umbi lapis menebal dan berdaging, warna merah keputihan, perbungaan berbentuk bongkol. Bawang merah dikenal sebagai obat, kira-kira sejak 5000 tahun yang lalu, bawang merah sudah dikenal dan digunakan oleh masyarakat mesir kuno. Hampir bersamaan waktunya dengan bawang putih, bawang merah tidak hanya dikenal sebagai bumbu penyedap masakan saja, tetapi juga untuk pengobatan. Baik digunakan secara sendirian, artinya hanya dengan bawang merah saja, maupun bersama bahan lain.,

Kandungan bawang merah diantaranya Minyak atsiri, Sikloaliin, Metilaiin, Dihidrolaiin, Flavongikosida, Kuersetin, Saponin. Dalam bawang merah mengandung asam glutamate yang merupakan natural essence (penguat rasa alamiah), terdapat juga senyawa propil disulfide dan propil metal disulfide yang mudah menguap. Jika dimanfaatkan sesuai dosis yang tepat, maka bawang merah dapat digunakan sebagai penurun suhu tubuh khususnya pada anak usia 1-5 tahun yang mengalami peningkatan suhu tubuh. Propil disulfide dan propil metal disulfide yang mudah menguap ini jika dibalurkan pada tubuh akan menyebabkan memungkinkan percepatan perpindahan panas dari tubuh ke kulit. ${ }^{8,9,10}$

Dari survey yang telah dilakukan di Puskesmas Lubuk Buaya Kota Padang, selain bawang merah didapatkan 2 dari 10 orang responden atau sebanyak $20 \%$ menggunakan obat tradisional, yaitu salah satunya menggunakan daun jarak sebagai penurun suhu tubuh ketika anak demam. Sedangkan 8 dari 10 responden atau sebanyak $80 \%$ menggunakan obat-obatan kimia sebagai penurun suhu tubuh anaknya ketika demam. Obat oral atau obat makan yang didapatkan dari puskesmas ternyata banyak 
dikeluhkan oleh ibu karena anaknya susah untuk minum obat, sehingga pemberian obat tidak maksimal diberikan pada anak. ${ }^{4}$

Menurut penelitian yang telah dilakukan oleh Suryono dan kawan-kawan di dusun Tertek Desa Tertek Kecamatan Pare pada bulan April 2010 dalam jurnal AKP, telah membuktikan bahwa bawang merah bisa menurunkan suhu tubuh pada anak demam dalam waktu 15 menit setelah bawang merah ditempelkan pada salah satu daerah tubuh, yakni telapak kaki, dada atau punggung sebanyak 3 siung untuk satu orang anak. ${ }^{10}$

Kejadian demam pada anak yang paling banyak terdapat di Kota Padang adalah di Puskesmas Lubuk Buaya, dengan angka 1067 orang anak mengalami demam sepanjang tahun 2016. Berdasarkan latar belakang yang telah dijelaskan, peneliti akan mencobakan keektifitasan penggunaan bawang merah untuk menurunkan suhu tubuh pada anak demam dengan usia dibawah 2 tahun. Bawang merah berfungsi sebagai obat tradisional yang dari dulunya dipercaya dan sudah terbukti sebagai obat penurun suhu tubuh. Bawang merah sudah lama menduduki tempat terhormat dalam ilmu kedokteran sebagai bermacam obat, seperti yang telah dijelaskan pada latar belakang.

\section{METODE PENELITIAN}

Metode ini merupakan penelitian eksperimental dengan jenis penelitian quasi eksperiment. Pemberian tumbukan bawang merah dilakukan di rumah anak yang telah berobat ke poli anak, sebelumnya diberikan pertanyaan sesuai dengan kriteria inklusi dan ekslusi diluar ruangan poli sebelum anak dipanggil ke dalam ruangan untuk diperiksa dan mendapatkan terapi yang akan diberikan. Lokasi penelitian dilakukan di puskesmas Lubuk Buaya Kota Padang dengan cara mendapatkan data atau alamat responden dari wawancara yang telah dilakukan kepada responden. Pelaksanaan intervensi pada bulan Januari 2018. Populasi dari penelitian ini adalah balita demam yang berobat ke poli anak di Puskesmas Lubuk Buaya Kota Padang. Sampel pada penelitian ini adalah anak demam usia dibawah 2 tahun, karena anak usia dibawah 2 tahun susah untuk diberi obat oral, anak usia dibawah 2 tahun lebih cenderung terkena demam karena masih memiliki sistem imun tubuh yang rendah dan sebaikanya dari sedini mungkin anak-anak dihindari dari pemberian obat-obatan yang mengandung bahan kimia ( seperti obat pil atau obat oral lainnya). Sampel sebanyak 16 balita, diambil menggunakakn teknik purposive sampling ( sesuai kriteria inklusi dan eksklusi ), intervensi dilakukan dirumah responden ( kunjungan rumah). Instrumen yang digunakan untuk pengumpulan data dalam penelitian yaitu : lembar observasi dan termometer. Analisis data menggunakan computer dan diolah menggunakan SPSS, terdiri dari : Analisis Univariat, hasil rata-rata suhu tubuh sebelum dan sesudah dilakukan pemberian tumbukan bawang merah. Analisis Bivariat, Untuk uji normalitas data pada analisis univariat digunakan uji Shapiro-Wilk, karena sampel kurang dari 50 orang.

\section{HASIL PENELITIAN}

\section{A. Hasil Penelitian \\ 1. Analisis Univariat}

Tabel 1.

Rerata Suhu Tubuh sebelum diberikan

Tumbukan Bawang Merah pada Balita Demam di Puskesmas Lubuk Buaya Kota Padang Tahun 2018

\begin{tabular}{lccccc}
\hline Variabel & N & $\begin{array}{l}\text { Mea } \\
\text { n }\end{array}$ & $\begin{array}{l}\text { Standar } \\
\text { Deviasi }\end{array}$ & Min & Maks \\
\hline $\begin{array}{l}\text { Suhu tubuh } \\
\text { sebelum di } \\
\text { berikan } \\
\text { tumbukan }\end{array}$ & & & & & \\
bawang merah & 16 & 37,91 & 0,15 & 37,7 & 38,3 \\
\hline
\end{tabular}

Berdasarkan tabel 1 diketahui dari 16 responden, di dapatkan hasil pengukuran suhu tubuh minimum sebelum dilakukan pemberian tumbukan bawang merah adalah $37,7^{\circ} \mathrm{C}$ dan hasil 
pengukuran suhu tubuh maksimum adalah $38,3^{\circ} \mathrm{C}$. Di dapatkan rata-rata suhu tubuh sebelum dilakukan pemberian tumbukan bawang merah adalah $37,91^{\circ} \mathrm{C}$, sedangkan standar deviasi suhu tubuh sebelum dilakukan pemberian tumbukan bawang merah adalah 0,15 .

Tabel 2

Rerata Suhu Tubuh sesudah diberikan Tumbukan Bawang Merah pada Balita Demam di Puskesmas Lubuk Buaya Kota Padang Tahun 2018

\begin{tabular}{lccccc}
\hline Variabel & N & Mean & $\begin{array}{c}\text { Stan } \\
\text { dar } \\
\text { Devia } \\
\text { si }\end{array}$ & Min & Maks \\
\hline $\begin{array}{l}\text { Suhu tubuh } \\
\text { setelah di } \\
\text { berikan } \\
\text { tumbukan } \\
\text { bawang } \\
\text { merah }\end{array}$ & 16 & 37,42 & 0,13 & 37,1 & 3,6 \\
\hline
\end{tabular}

Berdasarkan tabel 2 diketahui dari 16 responden, di dapatkan hasil pengukuran suhu tubuh minimum setelah dilakukan pemberian tumbukan bawang merah adalah $37,1^{\circ} \mathrm{C}$ dan hasil pengukuran suhu tubuh maksimum adalah $37,6^{\circ} \mathrm{C}$. Didapatkan rata-rata suhu tubuh setelah dilakukan pemberian tumbukan bawang merah adalah $37,42^{\circ} \mathrm{C}$, sedanglan standar deviasi suhu tubuh setelah dilakukan pemberian tumbukan bawang merah adalah 0,13 .

\section{Analisis Bivariat}

Tabel 3

Pengaruh Pemberian Tumbukan Bawang Merah pada Balita Demam di Puskesmas Lubuk Buaya Kota Padang Tahun 2018

\begin{tabular}{lcccc}
\hline \multicolumn{1}{c}{ Variabel } & N & Mean & $\begin{array}{l}\text { Standar } \\
\text { Deviasi }\end{array}$ & p value \\
\hline $\begin{array}{l}\text { Suhu tubuh sebelum } \\
\text { dan sesudah } \\
\text { pemberian tumbukan } \\
\text { bawang merah }\end{array}$ & 16 & 0,4875 & 0,1408 & 0,000 \\
\hline
\end{tabular}

Berdasarkan tabel 3 diketahui dari 16 responden, didapatkan hasil penurunan rata-rata suhu tubuh adalah 0,4875 , nilai standar deviasi 0,1408 dan nilai $p$ value $=0,000<0,005$.
IV. PEMBAHASAN

\section{Analisis Univariat}

a. Rerata Suhu Tubuh Sebelum dilakukan Pemberian Tumbukan Bawang Merah pada Balita Demam di Puskesma Lubuk Buaya Kota Padang Tahun 2018

Dari hasil pengukuran suhu tubuh yang dilakukan pada 16 balita demam, didapatkan suhu tubuh minimum sebelum dilakukan pemberian tumbukan bawang merah adalah $37,7^{\circ} \mathrm{C}$ dan hasil pengukuran suhu tubuh maksimum adalah $38,3^{\circ} \mathrm{C}$. Didapatkan rata-rata suhu tubuh sebelum dilakukan pemberian tumbukan bawang merah adalah $37,91^{\circ} \mathrm{C}$, sedangkan standar deviasi suhu tubuh sebelum dilakukan pemberian tumbukan bawang merah adalah 0,15 .

Demam adalah naiknya temperatur tubuh, demam merupakan gejala, bukan penyakit. Demam menunjukkan terjadinya suatu infeksi, luka atau peradangan pada tubuh dan sedang diatasi. Secara umum demam dapat di sebabkan oleh infeksi dan non infeksi, demam infeksi terjadi akibat masuknya mikroorganisme tertentu ke dalam tubuh, seperti bakteri dan virus. Demam non infeksi dapat disebabkan oleh faktor lain, seperti stress psikologi, kelelahan dan dehidrasi sampai 5 tahun yang lebih cenderung mengalami kejang demam. ${ }^{1,6,12}$

Dari penelitian yang pernah dilakukan oleh oleh Suryono dan kawan kawan di dusun Tertek Desa Tertek Kecamatan Pare pada bulan April 2010 dalam jurnal AKP menunjukkan bahwa suhu tubuh rata-rata sebelum diberikan perlakuan sebesar $37,97^{\circ} \mathrm{C}$ setelah diberikan perlakuan turun menjadi $37,57^{\circ} \mathrm{C}$, dengan standar deviasi sebesar 0,046. Median dan Modus suhu tubuh sebelum diberi perlakuan sebesar $38^{\circ} \mathrm{C}$ dan setelah diberi perlakuan menjadi $37,60^{\circ} \mathrm{C} .{ }^{1,10}$

Kebanyakan suhu tubuh ketika ditemukan di lapangan, anak-anak yang mengalami kenaikan suhu tubuh berkisar antara $37,7^{\circ} \mathrm{C}$ $38,3^{\circ} \mathrm{C}$ yaitu berumur $\geq 2$ tahun dengan diagnosa Commond Cold. Dari observasi dan wawancara yang telah dilakukan kepada orang tua responden, orang tua menyebutkan bahwa anak mereka lebih aktif bermain diluar rumah, baik 
pada saat cuaca terik ataupun hujan, Peneliti berasumsi bahwa, demam pada anak dapat disebabkan oleh banyaknya aktifitas yang dilakukan oleh anak diluar rumah dan karena cuaca yang ekstrim sehingga pada saat pemeriksaan didapatkan diagnosa Commond Cold.

Menurut peneliti, demam pada anak bisa disebabkan oleh beberapa faktor, bukan hanya dari faktor infeksi dan non infeksi saja. Demam pada anak juga bisa disebabkan oleh sistem imun tubuh yang rendah, biasanya ini sering terjadi bila seorang anak terlalu banyak bermain atau melakukan aktifitas diluar rumah pada saat cuaca ekstrim sehingga menyebabkan dehidrasi pada anak.

\section{b. Rerata Suhu Tubuh Sesudah dilakukan Pemberian Tumbukan Bawang Merah pada Balita Demam di Puskesmas Lubuk Buaya Kota Padang Tahun 2018}

Dari hasil pengukuran suhu tubuh pada 16 balita demam, didapatkan suhu tubuh minimum setelah dilakukan pemberian tumbukan bawang merah adalah $37,1^{\circ} \mathrm{C}$ dan Demam pada anak dapat menyebabkan kejang demam, terutama pada anak usia 6 bulan

hasil pengukuran suhu tubuh maksimum adalah $37,6^{\circ} \mathrm{C}$. Didapatkan rata-rata suhu tubuh setelah dilakukan pemberian tumbukan bawang merah adalah $37,42^{\circ} \mathrm{C}$, sedangkan standar deviasi suhu tubuh setelah dilakukan pemberian tumbukan bawang merah adalah 0,134.

Menurut teori, penurunan suhu tubuh setelah dilakukan pemberian tumbukan bawang merah adalah secara vasodilatasi. Vasodilatasi adalah pelebaran diameter pembulu darah yang terjadi ketika otot-otot di dinding pembulu darah mengendur (rileks). Vasodilatasi di sebabkan oleh hambatan dari pusat simpatis pada hipotalamus posterior yang menyebabkan vasokontriksi sehingga terjadi vasodilatasi yang kuat pada kulit yang kuat, yang memungkinkan percepatan perpindahan panas dari tubuh ke kulit. Dalam bawang merah terdapat senyawa propil disulfide dan propil metil disulfide, yang mana kedua senyawa ini mudah menguap. ${ }^{10}$

Dari penelitian yang pernah dilakukan oleh oleh Suryono dan kawan kawan di dusun Tertek
Desa Tertek Kecamatan Pare pada bulan April 2010 dalam jurnal AKP menunjukkan bahwa suhu tubuh rata-rata sebelum diberikan perlakuan sebesar $37,97^{\circ} \mathrm{C}$ setelah diberikan perlakuan turun menjadi $37,57^{\circ} \mathrm{C}$, dengan standar deviasi sebesar 0,046. Median dan Modus suhu tubuh sebelum diberi perlakuan sebesar $38^{\circ} \mathrm{C}$ dan setelah diberi perlakuan menjadi $37,60^{\circ} \mathrm{C}$. ${ }^{10}$

Penelitian dengan menggunakan tumbukan bawang merah yang ditempelkan pada punggung balita demam ini dapat menurunkan suhu tubuh, tetapi penurunan suhu tubuh bisa terjadi karena beberapa hal. Misalnya pada saat intervensi anak rewel dan susah untuk diberikan tumbukan bawang merah pada daerah punggung, sehingga bawang merah tidak bekerja secara maksimal pada saat ditempelkan karena anak banyak bergerak.

\section{Analisis Bivariat}

Data berdistribusi normal, maka pengujian hipotesis dilanjutkan dengan dilakukan pemberian tumbukan bawang merah adalah 0,48 , nilai standar deviasi 0,1408 dan nilai $p$ value $=0,000<0,05$. Hasil ini menunjukkan bahwa ada pengaruh pemberian tumbukan bawang merah pada balita demam usia dibawah 2 tahun di Puskesmas Lubuk Buaya Kota Padang tahun 2018.

Dari penelitian yang telah dilakukan oleh Suryono dan kawan-kawan menunjukkan bahwa suhu tubuh rata-rata sebelum diberi perlakuan sebesar $37,97^{\circ} \mathrm{C}$. Penurunan suhu tubuh setelah diberikan perlakuan menjadi $37,57^{\circ} \mathrm{C}$, dengan standar deviasi sebesar 0,04. Median dan Modus suhu tubuh sebelum diberi perlakuan sebesar $38^{\circ} \mathrm{C}$ dan setelah diberi perlakuan menjadi $37,6^{\circ} \mathrm{C}$. Didapatkan hasil $p=0,00 \quad(\alpha<0,05)$ berarti $p<\alpha$, sedangkan $\mathrm{t}$ hitung sebesar 33,00 sehingga Ho ditolak dan $\mathrm{H} 1$ diterima dengan demikian dapat disimpulkan bahwa ada pengaruh dari pemberian bawang merah terhadap penurunan suhu tubuh pada anak febris usia 1-5 tahun di Posyandu Boegenvile 1 Dusun Tertek Desa Tertek Kecamatan Pare tanggal 15 April 2010. ${ }^{10}$

Bayu Satya DS dan kawan-kawan menyebutkan dalam bukunya yang berjudul 
Koleksi Tumbuhan Berkhasiat bahwa bawang merah bisa digunakan sebagai penurun suhu tubuh pada anak demam. Di sini bawang merah digunakan bersamaan dengan minyak kelapa secukupnya dan minyak kayu putih secukupnya. Semua dicampur jadi satu di remas-remas, kemudian dioleskan pada seluruh badan anak demam. $^{7}$

Singgih Wibowo dan kawan-kawan menyebutkan dalam bukunya yang berjudul Budidaya Bawang Merah, Bawang Putih, Bawang Bombay bahwa bawang merah bisa digunakan tanpa menggunakan campuran bahan lain atau hanya bawang merah saja. Hal ini sesuai dengan penelitian yang telah dilakukan oleh Suryono dan kawan-kawan di dusun Tertek Desa Tertek Kecamatan Pare pada bulan April 2010 dalam jurnal AKP, telah membuktikan bahwa hanya dengan bawang merah saja tanpa menggunakan bahan menggunakan uji paired sample $t$ test. Hasil penurunan rata-rata suhu tubuh setelah lain bisa menurunkan suhu tubuh pada anak demam. Dari penelitian tersebut didapatkan terjadinya penurunan suhu tubuh dari 8 responden, yaitu penurunan suhu tubuh pada 3 anak yang bersuhu $37,50^{\circ} \mathrm{C}$ sebesar $37,50 \%$ dan 5 anak yang bersuhu $37,60^{\circ} \mathrm{C}$ sebesar $62,50 \% .^{14,10}$

Dalam bawang merah mengandung asam glutamate yang merupakan natural essence (penguat rasa alamiah), terdapat juga senyawa propil disulfide dan propil metal disulfide yang mudah menguap. Jika dimanfaatkan sesuai dosis yang tepat, maka bawang merah dapat digunakan sebagai penurun suhu tubuh khususnya pada anak usia 1-5 tahun yang mengalami peningkatan suhu tubuh. Propil disulfide dan propil metal disulfide yang mudah menguap ini jika dibalurkan pada tubuh akan menyebabkan vasodilatasi yang kuat pada kulit, yang memungkinkan percepatan perpindahan panas dari tubuh ke kulit. ${ }^{10}$

Berdasarkan hasil intervensi yang telah dilakukan setelah pemberian tumbukan bawang merah pada punggung balita demam, diketahui bahwa 12 dari 16 orang responden mempunyai diagnosa common cold dan 4 dari 16 orang responden mempunyai diagnosa ispa. Berdasarkan penurunan suhu tubuh yang telah didapatkan setelah memberikan intervensi, diketahui bahwa diagnosa yang telah didapatkan dari masing-masing anak demam tidak mempengaruhi pada penurunan suhu tubuh, karena pada anak yang mempunyai diagnosa ispa ataupun common cold cenderung mempunyai rerata penurunan suhu tubuh yang sama, yaitu $0,4^{\circ} \mathrm{C}$.

Penelitian ini bermanfaat untuk mengatasi balita demam, terlebih jika mengalami peningkatan suhu tubuh pada malam hari dan tidak tersedia obat penurun panas di rumah. Bawang merah dapat dijadikan alternatif pertama sebagai penurun suhu tubuh anak, karena bawang merah umumnya sudah tersedia di dapur rumah dan sering digunakan sebagai bahan masakan. Pemberian tumbukan bawang merah ini hanya efektif untuk anak yang mempunyai suhu tubuh tidak terlalu tinggi, yaitu $<39^{\circ} \mathrm{C}$, karena rata penurunan suhu tubuh pada setiap anak hanya 0,4 .

\section{KESIMPULAN}

Rerata suhu tubuh sebelum diberikan tumbukan bawang merah adalah $37,91^{\circ} \mathrm{C}$. Rerata suhu tubuh setelah diberikan tumbukan bawang merah adalah $37,42^{\circ} \mathrm{C}$. Hasil rerata perbedaan suhu tubuh sebelum dan sesudah dilakukan pemberian tumbukan bawang merah adalah 0,48 .

\section{DAFTAR PUSTAKA}

Danarti, Dessy. Kesehatan Bayi dan Anak. Yogyakarta: G-media; 2010.

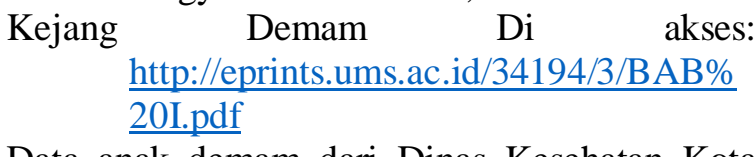

Data anak demam dari Dinas Kesehatan Kota Padang

Data anak demam dari Puskesmas Lubuk Buaya kota Padang Tahun 2016

Behrman, dkk. IlmuKesehatan Anak. Jakarta: EGC

Anurogo, Dito dan Ari Wulandari. Penyakit yang Banyak ditemukan di Masyrakat.Yogyakarta : Rapha Publishing; 2012.

Setya DS, Bayu. Koleksi Tumbuhan Berkhasiat. Yogyakarta: Rapha Publishing; 2013.

Wibowo, Singgih. Budidaya bawang putih, merah dan bombay. Jakarta: Penebar Swadaya anggota Ikapi; 2008. 
Volume 2 Nomor 2 P-ISSN : 2597-8594

Prasetya Subagja, Hamid. Kitab Ramuan Tradisional dan Herbal Nusantara. Jakarta: Transmedia; September 2013.

Suryono, Sukatmi, Tinuk Dwi Jayanti. Efektifitas Bawang Merah Sebagai Penurun Suhu Tubuh Pada Anak Febris Usia 1-5 Tahun. Jurnal AKP [Sumber Online] Juli- Desember 2012 [diakses 2 Agustus 2017]

Supani Ibunda dan Ari Wulandari. Herbal Nusantara : 1001 Ramuan Tradisional Asli Indonesia. Yogyakarta: Rapha Publishing; 2012.

Djunarko, Ipang dan Yosephine Dian Hendrawati. Swamedikasi yang Baik dan Benar. Yogyakarta: PT Intan Sejati; 2011.

Rahayu utami Ningsih, Wahyu. Menjadi Dokter Bagi Anak Anda. Yogyakarta: Cakrawala Ilmu; 2015.

Suparni, Ibunda. Manfaat dan Khasiat Sehat dari Dapur Anda. Yogyakarta: Rapha Publishing; 2013.

Budi Waskito, Setiawan. Tanaman Obat. Surakarta: CV Suara Media Sejahtera; 2008.

Widhi Nugroho, Aryandhito dan Shanti Haniyarti. Kegawatdaruratan Pediatri. Jakarta: EGC; 2011.

Herbie, Tandi. 226 Tumbuhan Obat untuk Penyembuhan Penyakit dan Kebugaran Tubuh. Yogyakarta: OCTOPUS Publishing House; 2015.

Probowati, Arie. Herbal Kalimantan, Ramuan Tradisional Asli dari Kalimantan. Yogyakarta: Rapha Publishing; 2017.

Arifin el-Basyier, Zainul. Sehat dengan 65 Tanaman Obat. Jakarta: PT Sunda Kelapa Pustaka; 2013.

Utami, Prapti. Diet Aman dan Sehat Berkat Herbal. Jakarta: FMedia (Imprint Agromedia Pustaka); 2013.

Sa'adah, Sumiyati. Budi Daya Bawang. Azka Mulia Media; 2007.

Notoatmodjo, Soekidjo. Metodologi Penelitian Kesehatan. Jakarta: Rineka Cipta; 2017.

Saryono, Mekar Dwi Anggraini. Metodologi dalam Bidang Kesehatan. Yogyakarta: Nuhamedika; 2013. 